\title{
Nitrous Oxide Production in Sputum from Cystic Fibrosis Patients with Chronic Pseudomonas aeruginosa Lung Infection
}

\author{
Mette Kolpen ${ }^{1,2}$, Michael Kühl' ${ }^{3,4,5}$, Thomas Bjarnsholt ${ }^{1,2}$, Claus Moser ${ }^{1}$, Christine Rønne Hansen ${ }^{6}$, \\ Lars Liengaard ${ }^{3}$, Arsalan Kharazmi ${ }^{1}$, Tanja Pressler ${ }^{6}$, Niels Høiby ${ }^{1,2}$, Peter Østrup Jensen ${ }^{1 *}$
}

1 Department of Clinical Microbiology, Rigshospitalet, Copenhagen, Denmark, 2 Department of International Health, Immunology and Microbiology, Faculty of Health Sciences University of Copenhagen, Copenhagen, Denmark, 3 Marine Biological Section, Department of Biology, University of Copenhagen, Helsingør, Denmark, 4 Plant Functional Biology and Climate Change Cluster, University of Technology Sydney, Sydney, Australia, 5 Singapore Centre on Environmental Life Sciences Engineering, Nanyang Technological University, Singapore, Singapore, 6 Copenhagen CF Centre, Rigshospitalet, Copenhagen, Denmark

\begin{abstract}
Chronic lung infection by Pseudomonas aeruginosa is the major severe complication in cystic fibrosis (CF) patients, where $P$. aeruginosa persists and grows in biofilms in the endobronchial mucus under hypoxic conditions. Numerous polymorphonuclear leukocytes (PMNs) surround the biofilms and create local anoxia by consuming the majority of $\mathrm{O}_{2}$ for production of reactive oxygen species (ROS). We hypothesized that $P$. aeruginosa acquires energy for growth in anaerobic endobronchial mucus by denitrification, which can be demonstrated by production of nitrous oxide $\left(\mathrm{N}_{2} \mathrm{O}\right)$, an intermediate in the denitrification pathway. We measured $\mathrm{N}_{2} \mathrm{O}$ and $\mathrm{O}_{2}$ with electrochemical microsensors in 8 freshly expectorated sputum samples from $7 \mathrm{CF}$ patients with chronic $P$. aeruginosa infection. The concentrations of $\mathrm{NO}_{3}{ }^{-}$and $\mathrm{NO}_{2}{ }^{-}$in sputum were estimated by the Griess reagent. We found a maximum median concentration of $41.8 \mu \mathrm{M} \mathrm{N} \mathrm{N}_{2} \mathrm{O}$ (range 1.4-157.9 $\mu \mathrm{M} \mathrm{N} \mathrm{N}_{2} \mathrm{O}$ ). The concentration of $\mathrm{N}_{2} \mathrm{O}$ in the sputum was higher below the oxygenated layers. In 4 samples the $\mathrm{N}_{2} \mathrm{O}$ concentration increased during the initial $6 \mathrm{~h}$ of measurements before decreasing for approximately $6 \mathrm{~h}$. Concomitantly, the concentration of $\mathrm{NO}_{3}{ }^{-}$decreased in sputum during 24 hours of incubation. We demonstrate for the first time production of $\mathrm{N}_{2} \mathrm{O}$ in clinical material from infected human airways indicating pathogenic metabolism based on denitrification. Therefore, $P$. aeruginosa may acquire energy for growth by denitrification in anoxic endobronchial mucus in CF patients. Such ability for anaerobic growth may be a hitherto ignored key aspect of chronic P. aeruginosa infections that can inform new strategies for treatment and prevention.
\end{abstract}

Citation: Kolpen M, Kühl M, Bjarnsholt T, Moser C, Hansen CR, et al. (2014) Nitrous Oxide Production in Sputum from Cystic Fibrosis Patients with Chronic Pseudomonas aeruginosa Lung Infection. PLoS ONE 9(1): e84353. doi:10.1371/journal.pone.0084353

Editor: Erich Gulbins, University of Duisburg-Essen, Germany

Received July 30, 2013; Accepted November 14, 2013; Published January 17, 2014

Copyright: (C) 2014 Kolpen et al. This is an open-access article distributed under the terms of the Creative Commons Attribution License, which permits unrestricted use, distribution, and reproduction in any medium, provided the original author and source are credited.

Funding: This work was funded by Faculty of Health and Medical Sciences, University of Copenhagen. The funders had no role in study design, data collection and analysis, decision to publish, or preparation of the manuscript.

Competing Interests: The authors have declared that no competing interests exist.

*E-mail: Peter.Oestrup.Jensen@regionh.dk

\section{Introduction}

Cystic fibrosis $(\mathrm{CF})$ is an autosomal recessive disease. It is caused by mutations in the cystic fibrosis trans-membrane conductance regulator gene [1] affecting apical ion transport. In the lungs, the defective ion transport results in endobronchial accumulation of thick, viscous mucus that prevents mucociliar cleaning of the lungs, and increases susceptibility to chronic respiratory infections $[2,3]$. Pseudomonas aeruginosa is a Gram-negative, gamma proteobacterium, which dominates chronic lung infections in CF patients and is considered the most serious complication of CF $[4,5]$. The chronic $P$. aeruginosa lung infection in CF patients is characterized by presence of endobronchial biofilm aggregates surrounded by numerous polymorphonuclear leukocytes (PMNs) [6,7]. Despite the bactericidal activity of the PMNs and intensive antibiotic therapy, these biofilms persist and grow in the endobronchial mucus of $\mathrm{CF}$ patients over many years $[7,8]$. P. aeruginosa can withstand the bactericidal activity of the PMNs by forming biofilms of the protective mucoid phenotype [9] and by quorum sensing (QS)-regulated production of leukolytic amounts of rhamnolipid [10-13]. The summoned PMNs produce reactive oxygen species (ROS) through a respiratory burst, which leads to intense depletion of molecular oxygen $\left(\mathrm{O}_{2}\right)$ [14], a common feature of infected endobronchial mucus in CF [6]. Biofilm formation may explain why $P$. aeruginosa survives the attacking PMNs, but it is not known how $P$. aeruginosa acquires the energy required for the observed growth in endobronchial secretions [8] when $\mathrm{O}_{2}$ is absent. However, $P$. aeruginosa can grow anaerobically with alternative electron acceptors or by arginine fermentation [15], and it has been suggested that $P$. aeruginosa can respire by denitrification in anoxic $\mathrm{CF}$ mucus utilizing nitrate $\left(\mathrm{NO}_{3}{ }^{-}\right)$and nitrite $\left(\mathrm{NO}_{2}{ }^{-}\right)$, which are both present in sufficient amounts $[15,16]$. Although the ability of $P$. aeruginosa to utilize reduction of NOx for anaerobic respiration is well known [17], denitrification in mucus and persistent biofilms present in the airways of $\mathrm{CF}$ patients remains to be demonstrated. Since $\mathrm{N}_{2} \mathrm{O}$ is a natural intermediate belonging to the gases defining denitrification [17], we used electrochemical microsensors [18] to measure $\mathrm{O}_{2}$ and 
$\mathrm{N}_{2} \mathrm{O}$ concentration gradients at high spatio-temporal resolution in freshly expectorated sputum from CF patients with chronic $P$. aeruginosa lung infection.

Further evidence for denitrification was obtained from nitrate $\left(\mathrm{NO}_{3}{ }^{-}\right)$and nitrite $\left(\mathrm{NO}_{2}{ }^{-}\right)$turnover measurements in the sputum samples. These measurements provided important new insights to the micro-environmental conditions and chemical dynamics associated with persistent $P$. aeruginosa lung infections in CF patients and indicate that nitrogen compounds can play an important role in the interaction between pathogenic bacteria and an active immune response.

\section{Results}

$\mathrm{N}_{2} \mathrm{O}$ and $\mathrm{O}_{2}$ in sputum from CF patients with chronic $P$. aeruginosa lung infection

Representative measurements of $\mathrm{O}_{2}$ and $\mathrm{N}_{2} \mathrm{O}$ in freshly expectorated sputum were acquired with $\mathrm{O}_{2-}$ and $\mathrm{N}_{2} \mathrm{O}$ microsensors (Fig 1A). Measurements of $\mathrm{O}_{2^{-}}$and $\mathrm{N}_{2} \mathrm{O}$ profiles in expectorated sputum from a CF patient with chronic $P$. aeruginosa lung infection showed the distribution of an upper oxygenated zone and a lower anoxic zone. The $\mathrm{N}_{2} \mathrm{O}$ profile reached the maximal concentration of $\mathrm{N}_{2} \mathrm{O}$ in the lower anoxic part of the sputum sample, suggesting that denitrification is mainly confined to the anoxic zone. A slow decline of $\mathrm{O}_{2}$ was apparently detected above the sputum surface. This may be because the position of the sputum surface was estimated by visual inspection, which is associated with uncertainty due to small amounts of heterogeneous saliva (Fig 1B).

Sputum is composed of heterogeneously distributed bacterial aggregates surrounded by $\mathrm{PMNs}$ consuming $\mathrm{O}_{2}$, and this respiratory burst creates local anoxic microenvironments in the sputum [14]. The metabolic mechanisms are thus compartmentalized according to the availability of $\mathrm{O}_{2}$ with an oxygenated zone, wherein the majority of $\mathrm{O}_{2}$ is reduced to superoxide by the summoned PMNs, and an anoxic zone, where $P$. aeruginosa can utilize nitrate as electron acceptor during oxidative phosphorylation (Fig. 1G).

\section{$\mathrm{NO}_{3}{ }^{-}$and $\mathrm{NO}_{2}{ }^{-}$in sputum from $\mathrm{CF}$ patients with chronic} $P$. aeruginosa lung infection

$\mathrm{NO}_{3}{ }^{-}$and $\mathrm{NO}_{2}{ }^{-}$concentrations in sputum samples were measured before $\mathrm{N}_{2} \mathrm{O}$ profiling and 1 day later (Fig 2). The concentration of $\mathrm{NO}_{3}{ }^{-}$was significantly higher immediately before $\mathrm{N}_{2} \mathrm{O}$ profiling as compared to 1 and 2 days after incubation indicating $\mathrm{NO}_{3}{ }^{-}$depletion due to ongoing denitrification (Fig 2A, B). The $\mathrm{NO}_{2}{ }^{-}$concentration was not changed significantly after one day (Fig 2C), but by including additional measurements of the $\mathrm{NO}_{2}{ }^{-}$concentration in 7 sputum samples a significantly decreased $\mathrm{NO}_{2}{ }^{-}$concentration was detected (Fig 2D).

\section{Distribution of $\mathrm{N}_{2} \mathrm{O}$ in sputum from $\mathrm{CF}$ patients with chronic $P$. aeruginosa lung infection}

Vertical profiles of $\mathrm{O}_{2}$ in sputum samples showed depletion of $\mathrm{O}_{2}$, indicating the formation of anoxic zones below a mean depth of $3.1 \mathrm{~mm}$ (SD $=3.0 \mathrm{~mm}$ ) from the sputum surface (Fig $3 \mathrm{~A}$ ) suggesting that the average depth of $\mathrm{O}_{2}$ penetration of $\sim 3 \mathrm{~mm}$. A higher concentration of $\mathrm{N}_{2} \mathrm{O}$ was observed in the anoxic zone as compared to the oxic zone $(\mathrm{p}<0.026, \mathrm{n}=8)$ (Fig 3B). To verify that $\mathrm{N}_{2} \mathrm{O}$ is related to $P$. aeruginos $a$ we found significantly less $\mathrm{N}_{2} \mathrm{O}$ in three control sputum samples from $1 \mathrm{CF}$ patient and from 2

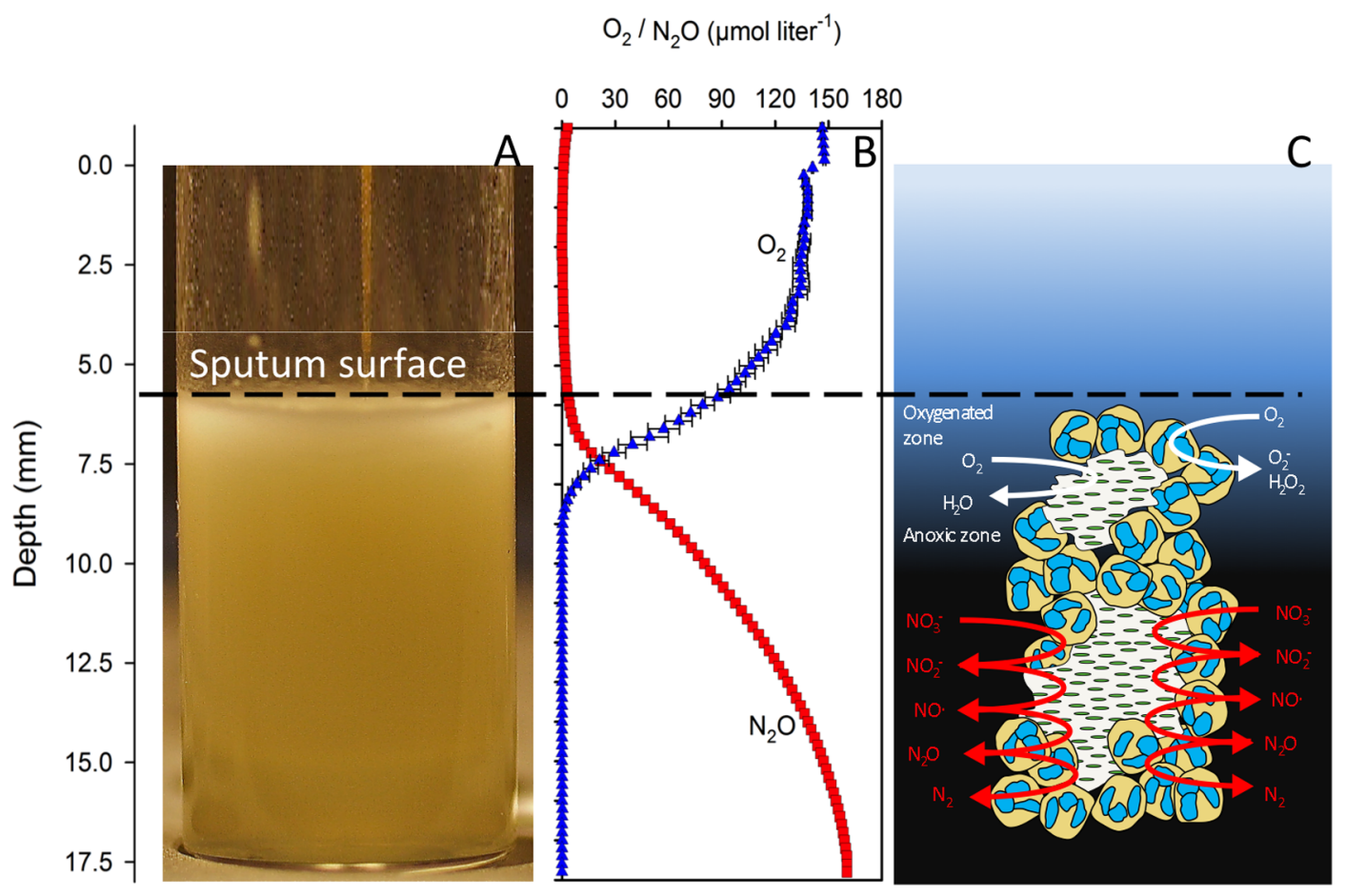

Figure 1. Microsensor measurements of chemical gradients in sputum. (A) Close up of a sputum sample from a cystic fibrosis patient with chronic $P$. aeruginosa lung infection with an inserted microsensor. (B) Representative microprofiles of $\mathrm{N}_{2} \mathrm{O}$ and $\mathrm{O}_{2}$ in a CF sputum sample. $\mathrm{O}_{2}$ profiles are shown as the mean and SD of three microprofiles recorded in the beginning of the experiment and did not change significantly throughout the experimental period, while the $\mathrm{N}_{2} \mathrm{O}$ profile represents the maximal $\mathrm{N}_{2} \mathrm{O}$ levels measured about $6-7 \mathrm{~h}$ after beginning. (C) A schematic model of the involved PMN and biofilm processes in CF sputum explaining the microprofiles.

doi:10.1371/journal.pone.0084353.g001 
A
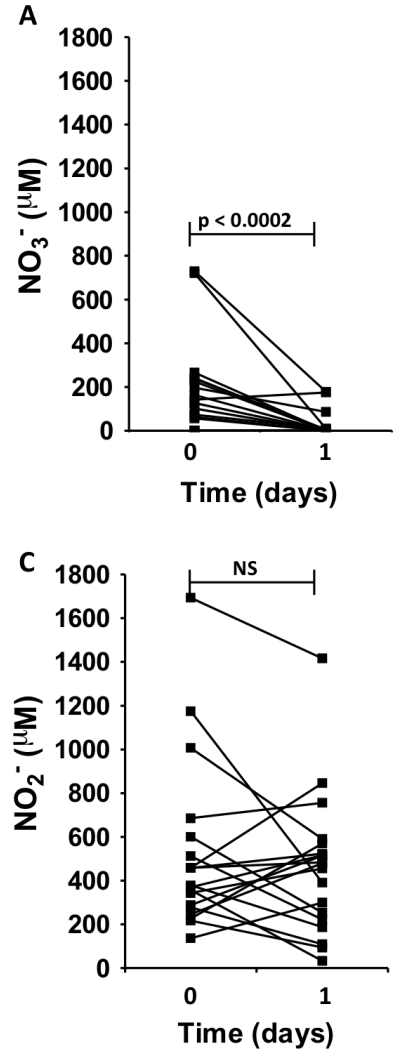
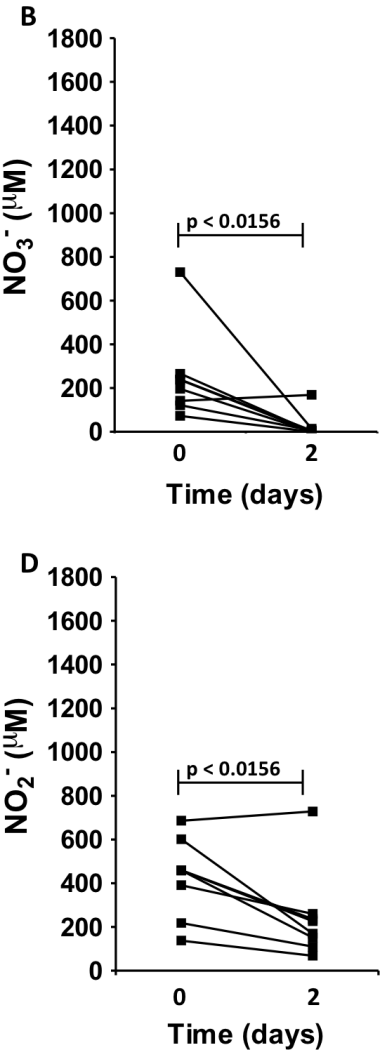

Figure 2. Consumption of $\mathrm{NO}^{-}$and $\mathrm{NO}^{-}$in sputum. (A, B) $\mathrm{NO}_{3}{ }^{-}$concentration in sputum samples from cystic fibrosis patients with chronic $P$. aeruginosa lung infection. (C, D) $\mathrm{NO}_{2}{ }^{-}$concentration in sputum samples from cystic fibrosis patients with chronic $P$. aeruginosa lung infection. Samples were collected immediately after expectoration and after $1(n=20)$ and 2 days $(n=7)$ of incubation. Data were analyzed by Wilcoxon signed rank test.

doi:10.1371/journal.pone.0084353.g002

primary ciliary dyskinesia (PCD) patients without detectable $P$. aeruginosa $(\mathrm{p}<0.030)$.

\section{Dynamics of $\mathrm{N}_{2} \mathrm{O}$ in sputum from a CF patient with chronic $P$. aeruginosa lung infection}

Figure 4 displays time series of representative $\mathrm{N}_{2} \mathrm{O}$ profiles measured vertically through a sputum sample. The distribution of $\mathrm{O}_{2}$ is displayed at $0 \mathrm{hr}$. During the initial measuring period, $\mathrm{N}_{2} \mathrm{O}$ accumulated in the anoxic zone reaching a maximum concentration of $160 \mu \mathrm{M}$ after $6.5 \mathrm{~h}$ incubation, which indicates ongoing production of $\mathrm{N}_{2} \mathrm{O}$. Within the subsequent 4 hours the accumulated $\mathrm{N}_{2} \mathrm{O}$ decreased indicating consumption through reduction to $\mathrm{N}_{2}$.

\section{Rates of $\mathrm{N}_{2} \mathrm{O}$ production and consumption in sputum samples}

Measurements of the $\mathrm{N}_{2} \mathrm{O}$ concentration dynamics over time in particular depths of a sputum sample showed an initial build-up of $\mathrm{N}_{2} \mathrm{O}$ in layers below $7 \mathrm{~mm}$ (Fig. 5). In each layer, the slope of the net production curves was quasi-linear after $\sim 180 \mathrm{~min}$ indicating a constant production of $\mathrm{N}_{2} \mathrm{O}$ related to the particular layer and therefore that $\mathrm{N}_{2} \mathrm{O}$ originates from immobile sources such as biofilm. The production ceased about $6-7 \mathrm{~h}$ after start of the sample incubation, and was then followed by a net consumption of $\mathrm{N}_{2} \mathrm{O}$ over the following $4-5 \mathrm{~h}$ leading to $\mathrm{N}_{2} \mathrm{O}$ depletion in the

sputum sample after $\sim 10-12$ hours. In 4 sputum samples it was possible to estimate $\mathrm{N}_{2} \mathrm{O}$ production and consumption rates (Table 1) and $\mathrm{N}_{2} \mathrm{O}$ flux rates and cumulated emission (Figure 6) from measurements of such dynamic $\mathrm{N}_{2} \mathrm{O}$ concentration microgradients. A substantial initial $\mathrm{N}_{2} \mathrm{O}$ concentration was observed in the anaerobic zone of the remaining 4 assayed sputum samples. In these samples the $\mathrm{N}_{2} \mathrm{O}$ concentration decreased steadily during incubation.

\section{Discussion}

The ability of microorganisms to exploit a wide range of electron acceptors for ATP generation by oxidative phosphorylation provides metabolic flexibility in transient environments as these organisms inhabit a variety of habitats ranging from soils, sediments to aquatic environments [19]. Even though several human pathogens, including $P$. aeruginosa, are equipped with the genetic setup for denitrification [20-22] including nitric oxide reductase (NOR) [22], we present the very first observations of $\mathrm{N}_{2} \mathrm{O}$ production in clinical material from infected human airways demonstrating pathogenic metabolism based on denitrification. These data indicate that denitrification may serve as an alternative metabolic pathway allowing $P$. aeruginosa to thrive in $\mathrm{O}_{2}$ depleted micro niches in the airways of CF patients. Besides our study, denitrification in humans has previously been demonstrated in human dental plaque [23] and has been related to infections of the gastrointestinal tract by the increased concentration of $\mathrm{N}_{2} \mathrm{O}$ in exhaled breath from patients after oral intake of $\mathrm{NO}_{3}{ }^{-}$[24].

Seminal observations of $\mathrm{O}_{2}$ depletion and the presence of $\mathrm{OprF}$ porin, which is involved in $\mathrm{NO}_{3}{ }^{-}$and $\mathrm{NO}_{2}{ }^{-}$diffusion, in habitats of $P$. aeruginosa during chronic lung infection of CF patients provided initial evidence for anaerobic respiration by denitrification $[6,16]$. To demonstrate denitrification we have included CF patients, who suffered from chronic $P$. aeruginosa infection in the endobronchial mucus as detected by routine culturing. We revealed a depletion of $\mathrm{O}_{2}$ in $\mathrm{CF}$ sputum samples, which is in accordance with the steep $\mathrm{O}_{2}$ gradients in endobronchial $\mathrm{CF}$ mucus [6] and due to $\mathrm{O}_{2}$ consumption by activated PMNs for generation of $\operatorname{ROS}$ [14]. Our $\mathrm{O}_{2}$ measurements in sputum confirmed the presence of $\mathrm{O}_{2}$ concentration gradients reaching anoxia $\sim 3 \mathrm{~mm}$ below the sputum surface.

The depletion of $\mathrm{O}_{2}$ for microbial respiration in infected endobronchial $\mathrm{CF}$ mucus has motivated the present and several other studies of anaerobic metabolism by $P$. aeruginosa based on denitrification during chronic lung infection in CF. We demonstrated $\mathrm{N}_{2} \mathrm{O}$ production and consumption in the sputum samples indicating the presence of active NOR and nitrous oxide reductase $\left(\mathrm{N}_{2} \mathrm{OR}\right)$ for the reduction of nitric oxide (NO•) and $\mathrm{N}_{2} \mathrm{O}$ [17]. Previously, NOR has been isolated from $P$. aeruginosa [25], the genes $($ nor $C B)$ have been sequenced [26] and functional NOR has been observed in clinical strains of $P$. aeruginosa by consumption of $\mathrm{NO} \cdot[27]$.

In our study, the initial phase of $\mathrm{N}_{2} \mathrm{O}$ production in the sputum samples was followed by a period of net $\mathrm{N}_{2} \mathrm{O}$ consumption suggesting a depletion of $\mathrm{NO} \bullet$ and a concomitant reduction of $\mathrm{N}_{2} \mathrm{O}$ to $\mathrm{N}_{2}$ by $\mathrm{N}_{2} \mathrm{OR}$. The $\mathrm{N}_{2} \mathrm{O}$ consumption is in agreement with the demonstration of $\mathrm{N}_{2} \mathrm{OR}$ activity and the identification of the nos genes in $P$. aeruginosa [28] as well as the induced genes for a $\mathrm{N}_{2} \mathrm{OR}$ precursor in clinical isolates [29].

Our demonstration of significant $\mathrm{N}_{2} \mathrm{O}$ production in sputum indicates ample presence of $\mathrm{NO}_{3}{ }^{-}$and $\mathrm{NO}_{2}{ }^{-}$that serve as electron acceptors for the denitrification pathway. We found high levels of $\mathrm{NO}_{3}{ }^{-}$and $\mathrm{NO}_{2}{ }^{-}$in the sputum, which are in agreement with previous findings [30-32]. It has been proposed that $\mathrm{NO}_{3}{ }^{-}$ 


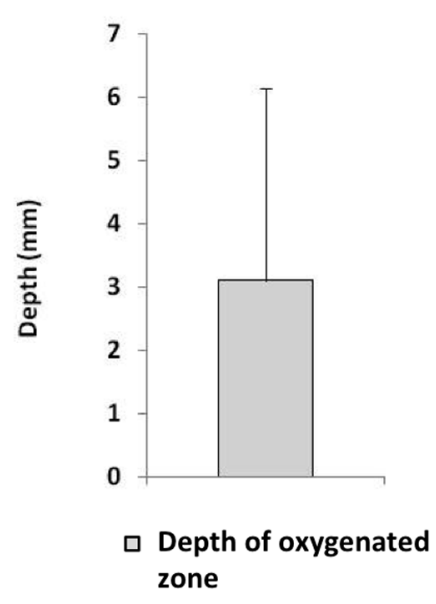

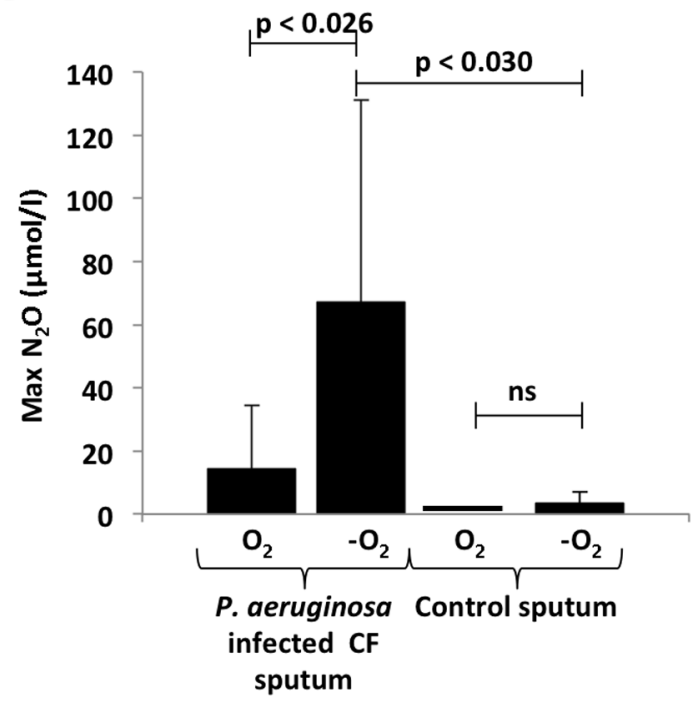

Figure 3. Distribution of $\mathbf{O}_{\mathbf{2}}$ and $\mathbf{N}_{\mathbf{2}} \mathbf{O}$ in sputum. (A) Depth of oxygenated zone in sputum samples from cystic fibrosis patients with chronic $P$. eruginosa lung infection $(n=8)$. (B) Maximal $\mathrm{N}_{2} \mathrm{O}$ concentration in the oxic zone and anoxic zone in sputum samples from cystic fibrosis patients with chronic $P$. aeruginosa lung infection $(n=8)$. Control sputum without detectable $P$. aeruginosa was obtained from two PCD patients and one CF patient. Statistical analysis was performed by Student t-test. doi:10.1371/journal.pone.0084353.g003

and $\mathrm{NO}_{2}{ }^{-}$in $\mathrm{CF}$ sputum originates from the rapid reaction between superoxide $\left(\mathrm{O}_{2}^{-}\right)$and $\mathrm{NO} \cdot[15]$. In this regard, we suggest the summoned activated PMNs [14] as a major source of $\mathrm{O}_{2}^{-}$, while NO•, which is present in CF exhaled breath [33,34], may be produced by a variety of cells in the lungs. In fact, inhalation of NO• or incubation of sputum samples with $\mathrm{NO}$ - resulted in elevated levels of $\mathrm{NO}_{3}{ }^{-}$and $\mathrm{NO}_{2}{ }^{-}$in sputum from $\mathrm{CF}$ patients [35]. In addition, ongoing activity of the patients nitric oxide synthases was evidenced by the increased exhaled $\mathrm{NO} \cdot$ from infected CF patients following supplementation with the substrate L-arginine [36,37].

As a consequence of our demonstration of $\mathrm{N}_{2} \mathrm{O}$ production, we expected a consumption of the precursors $\mathrm{NO}_{3}{ }^{-}$and $\mathrm{NO}_{2}{ }^{-}$. Accordingly, $\mathrm{NO}_{3}{ }^{-}$was depleted in the sputum after incubation for 1 day, which likely is due to the membrane-bound nitrate reductase of $P$. aeruginosa [29]. $\mathrm{NO}_{3}{ }^{-}$consumption may also accompany assimilatory denitrification and ammonification resulting in the formation of ammonia $\left(\mathrm{NH}_{4}{ }^{+}\right)$[17], which has been detected in CF sputum [27]. However, assimilatory denitrification and ammonification does not involve production of $\mathrm{N}_{2} \mathrm{O}$ $[17,38,39]$ and $\mathrm{NH}_{4}{ }^{+}$is also produced by several human cell types [40]. The concentration of $\mathrm{NO}_{2}{ }^{-}$was not changed during 1 day of incubation, but after 2 days of incubation the concentration of $\mathrm{NO}_{2}{ }^{-}$in the sputum was decreased significantly. This indicates that the production of $\mathrm{NO} \cdot$ from $\mathrm{NO}_{2}{ }^{-}$is slower than the generation of $\mathrm{NO}_{2}{ }^{-}$resulting from reduction of $\mathrm{NO}_{3}{ }^{-}$. Indeed, during reduction of $\mathrm{NO}_{3}{ }^{-}$transient accumulation of $\mathrm{NO}_{2}{ }^{-}$is known from anaerobic cultures of $P$. aeruginosa growing by denitrification [16,41,42].

A further verification of ongoing dissimilatory denitrification in sputum is evident from the calculated rate of $\mathrm{N}_{2} \mathrm{O}$ production (Fig. 6A), which easily can explain the depletion of $\mathrm{NO}_{3}{ }^{-}$during incubation (Fig. 2A). The depletion of $\mathrm{NO}_{3}{ }^{-}$in the sputum samples indicates that the $\mathrm{NO}_{3}{ }^{-}$in sputum samples is not replaced by the reaction between $\mathrm{O}_{2}{ }^{-}$and NO. This is possibly due to lack of contributions from immigrating PMNs and the epithelia as opposed to the conditions in the endobronchial mucus.
Since we calculated the rates of $\mathrm{N}_{2} \mathrm{O}$ production by assuming linear changes between subsequent measurements in the beginning of incubation, the estimates are likely to reflect the situation in the endobronchial mucus, where reduced $\mathrm{NO}_{3}{ }^{-}$and $\mathrm{NO}_{2}{ }^{-}$is continuously being replaced as indicated by the high $\mathrm{NO}_{3}{ }^{-}$and $\mathrm{NO}_{2}{ }^{-}$content in fresh sputum. The estimated $\mathrm{N}_{2} \mathrm{O}$ production, however, is calculated from the actual $\mathrm{N}_{2} \mathrm{O}$ content and does not include the reduction of $\mathrm{N}_{2} \mathrm{O}$ to $\mathrm{N}_{2}$. Therefore, the actual rate of denitrification may be higher than our estimates.

We found the highest concentration of $\mathrm{N}_{2} \mathrm{O}$ in the anoxic zone of the confined sputum samples indicating higher rate of denitrification without $\mathrm{O}_{2}$ as previously demonstrated [43]. Accordingly, we suggest that the low concentration of $\mathrm{N}_{2} \mathrm{O}$ found in the oxygenated zone is mainly due to diffusion from the active anoxic zone. Additionally, our estimate of the depth of the oxygenated zone implies that the bronchi, with diameters ranging from 0.8 to $13 \mathrm{~mm}[44,45]$, allow for numerous anoxic zones in the endobronchial mucus of the lungs and confirms the in vivo demonstration of $\mathrm{O}_{2}$ depletion in the endobronchial mucus [6]. Consequently, our results propose the existence of several zones with $\mathrm{N}_{2} \mathrm{O}$ production in the anoxic endobronchial mucus of the lungs of $\mathrm{CF}$ patients with chronic $P$. aeruginosa lung infection. However, such in vivo production of $\mathrm{N}_{2} \mathrm{O}$ in $\mathrm{CF}$ patients still awaits direct experimental confirmation.

The involvement of denitrification enzymes as terminal oxidases that reduce nitrogen oxides in the highly branched respiratory chain of $P$. aeruginosa may enable anaerobic growth in the presence of nitrate or nitrite $[19,46]$. But the engagement of denitrification in $P$. aeruginosa may also contribute to virulence as evidenced by the finding of antibodies directed against components of denitrification in CF patients with $P$. aeruginosa lung infection $[16,47]$ and the dependence on nitrite reductase for type III secretion [48]. In anaerobic cultures, denitrification promotes growth of $P$. aeruginosa [49], increases antibiotic tolerance of $P$. aeruginosa [50] and favors maintenance of the virulent mucoid phenotype [30].

A particular contribution to the pathogenesis of chronic lung infection in CF by NOR activity, is suggested by the induced in vivo 




Figure 4. Generation and depletion of $\mathbf{N}_{\mathbf{2}} \mathrm{O}$ in sputum. Spatio-temporal dynamics of $\mathrm{N}_{2} \mathrm{O}$ concentration profiles in a representative sputum sample from a cystic fibrosis patient with chronic $P$. aeruginosa lung infection showing initial accumulation of $\mathrm{N}_{2} \mathrm{O}$ in the anoxic zone followed by total depletion. The $\mathrm{O}_{2}$ concentration profile is shown as the mean and SD of three microprofiles recorded at the beginning of the experiment. doi:10.1371/journal.pone.0084353.g004

gene expression in clinical isolates [29] including the highly virulent mucoid isolates [51]. In this respect, the reduction of NO• to $\mathrm{N}_{2} \mathrm{O}$ by active NOR may actually protect $P$. aeruginosa from the bactericidal action of $\mathrm{NO} \cdot$ generated by the immune system. In fact, NOR-deficient $P$. aeruginosa is more susceptible to NO• generated by macrophages [52] and less virulent during infection of silkworm [53]. In addition, NOR activity increases the virulence of several pathogens [54-56].

In conclusion, this study points to the presence of anoxic microenvironments with strong spatio-temporal heterogeneity as well as a possible stratification of metabolic processes in the biofilm aggregates characteristic of chronic $P$. aeruginosa infections in the airways of CF patients. Such structural and metabolic heterogeneity may be a characteristic trait ensuring persistent infection. Indeed, spatio-temporal resolved measurements enabled the demonstrated of $\mathrm{N}_{2} \mathrm{O}$ production in the anaerobic zones of freshly expectorated sputum samples from CF patients with chronic $P$. aeruginosa lung infection for the first time. Analysis of the $\mathrm{N}_{2} \mathrm{O}$ production rates suggests ongoing generation of $\mathrm{N}_{2} \mathrm{O}$ in the lungs of $\mathrm{CF}$ patients with chronic $P$. aeruginosa infection. $\mathrm{N}_{2} \mathrm{O}$ production 


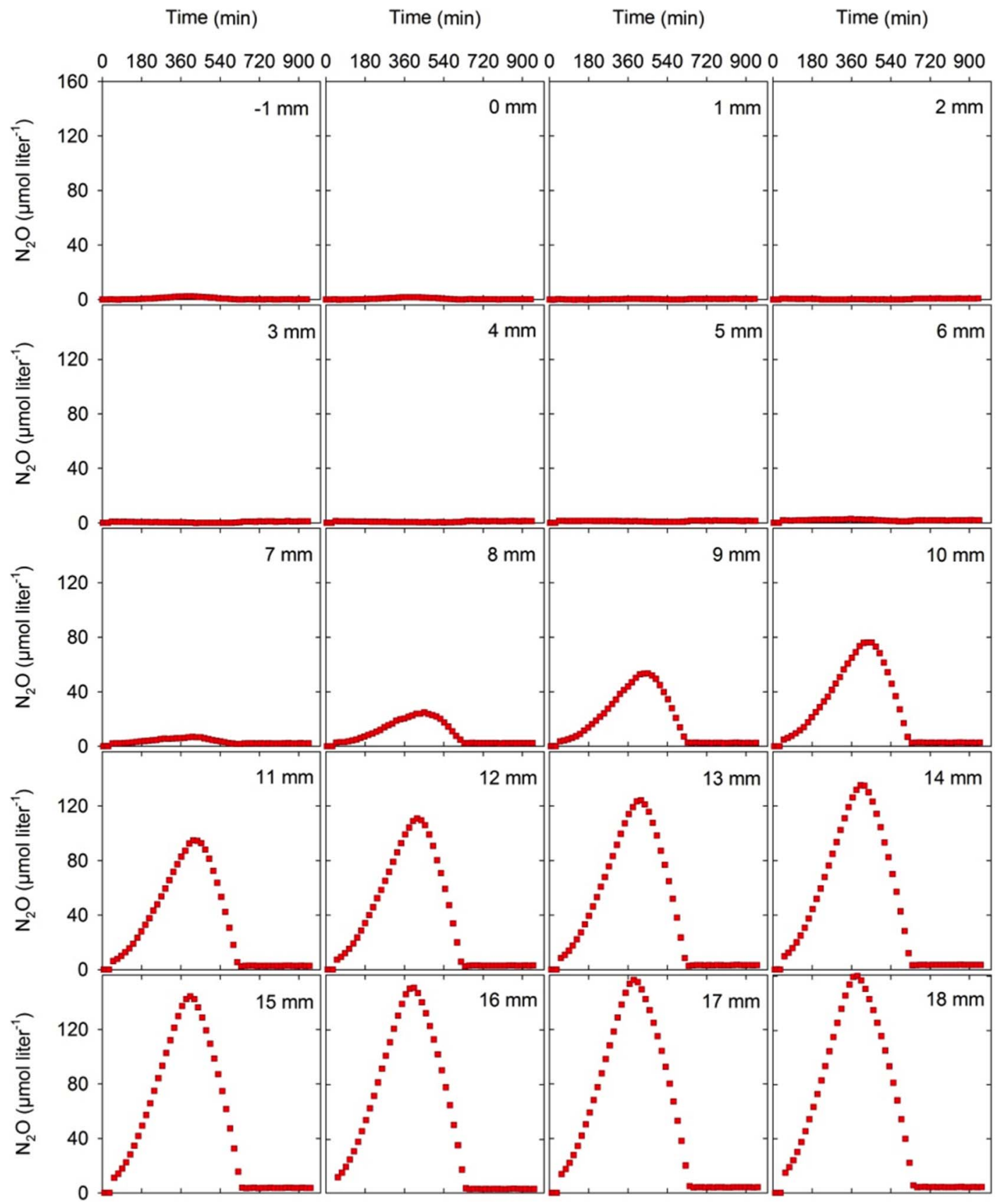

Figure 5. Rates of $\mathbf{N 2 O}$ production and consumption in sputum. Depth specific plots of $\mathrm{N}_{2} \mathrm{O}$ concentration vs. time at particular measuring depths in the same sputum sample as displayed in Fig 4. Accumulation and thus net production of $\mathrm{N}_{2} \mathrm{O}$ in all depths was observed until approximately $6 \mathrm{~h}$, followed by net consumption of $\mathrm{N}_{2} \mathrm{O}$ presumably due to depletion of nitrate around $6 \mathrm{~h}$. doi:10.1371/journal.pone.0084353.g005

Table 1. $\mathrm{N}_{2} \mathrm{O}$ production, consumption, max emission, and cumulated emission in $4 \mathrm{CF}$ sputum samples.

\begin{tabular}{|c|c|c|c|c|}
\hline & Net production rate & Net consumption rate & Max emission & Cumulated emission \\
\hline & $\left(\mathrm{nmol} \mathrm{cm} \mathrm{cm}^{-3} \mathrm{~min}^{-1}\right)$ & $\left(\mathrm{nmol} \mathrm{cm} \mathrm{cm}^{-3} \mathrm{~min}^{-1}\right)$ & $\left(\mathrm{nmol} \mathrm{cm} \mathrm{cm}^{-2} \mathrm{~min}^{-1}\right)$ & $\left(\mathrm{nmol} \mathrm{cm} \mathrm{cm}^{-2}\right)$ \\
\hline Median & 0.47 & -0.39 & $5.06 \times 10^{-5}$ & $1.05 \times 10^{-2}$ \\
\hline Range & $0.40-0.70$ & $-0.77--0.10$ & $1.8 \times 10^{-5}-6.78 \times 10^{-5}$ & $3.94 \times 10^{-3}-1.46 \times 10^{-2}$ \\
\hline
\end{tabular}

doi:10.1371/journal.pone.0084353.t001 
A

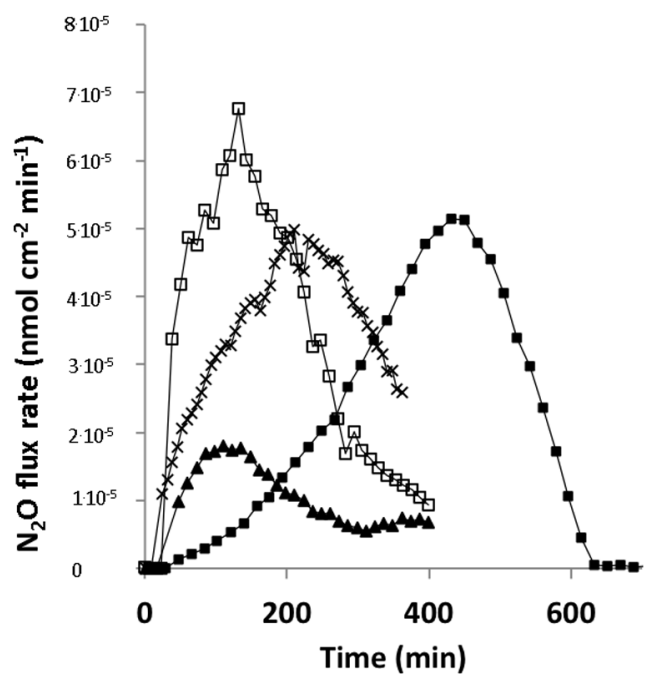

B

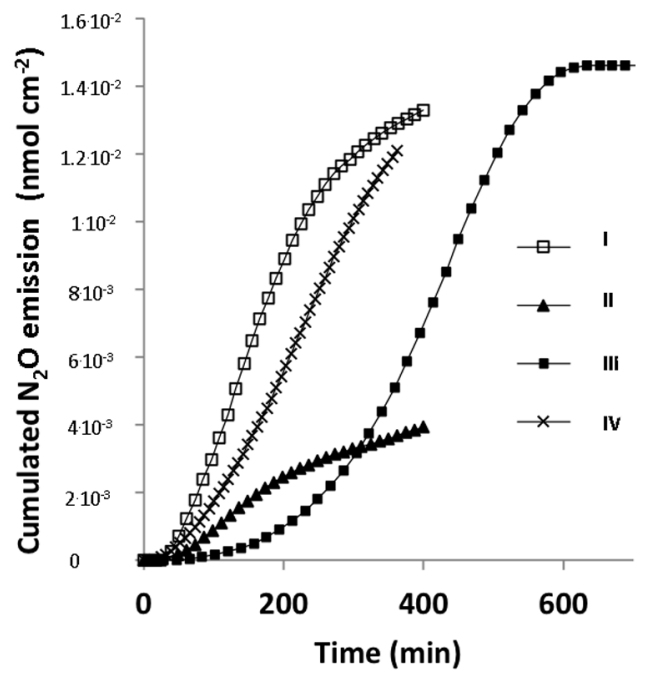

Figure 6. Efflux and cumulated emission of $\mathrm{N}_{2} \mathrm{O}$ from sputum samples. (A) Estimated $\mathrm{N}_{2} \mathrm{O}$ efflux rates in sputum samples from cystic fibrosis patients with chronic $P$. aeruginosa lung infection as calculated from $\mathrm{N}_{2} \mathrm{O}$ microprofiles $(n=4)$. (B) Cumulated $\mathrm{N}_{2} \mathrm{O}$ emission as calculated from $\mathrm{N}_{2} \mathrm{O}$ microprofiles $(n=4)$. I, II, III and IV represents 4 different sputum samples. doi:10.1371/journal.pone.0084353.g006

by $P$. aeruginosa in this environment is associated with anaerobic growth, which can promote increased virulence and tolerance to antibiotic, as well as contribute to evasion of the host response. The chronic infected CF lung is in many ways a black box. By using the presented approach to elucidate the essential metabolites we may now open the black box and start mapping the microenvironment of infection which may inspire new strategies for prevention and treatment of chronic lung infections in CF.

\section{Materials and Methods}

\section{Sputum Samples}

As defined by the "Danish Act on Research Ethics Review of Health Research Projects" Section 2 the project does not constitute a health research project and was thus initiated without approval from The Committees on Health Research Ethics in the Capital Region of Denmark. Therefore, verbal informed consent was obtained using waiver of documentation of consent. The study was carried out on 21 anonymized samples of surplus expectorated sputum from $21 \mathrm{CF}$ patients and 2 PCD patients (Table 2). Chronic $P$. aeruginosa infection was defined as the presence of $P$. aeruginosa in the lower respiratory tract at each monthly culture for $>6$ months, or for a shorter time in the presence of increased antibody response to $P$. aeruginosa $(>2$ precipitating antibodies, normal: 0-1) [57].

Microsensor Measurements of $\mathbf{O}_{2}$ and $\mathbf{N}_{2} \mathbf{O}$. Each of 8 different sputum samples $(1-2 \mathrm{ml})$ was added to a glass vial $(35 \times 12 \mathrm{~mm})$ (Schuett Biotec, Germany) and allowed to settle for about $10 \mathrm{~min}$. The glass vials were positioned in a heated metal rack, kept at $37^{\circ} \mathrm{C}$. Vertical $\mathrm{O}_{2}$-concentration profiles were recorded in the sputum with an amperometric $\mathrm{O}_{2}$ microsensor (OX25, Unisense A/S, Århus, Denmark) mounted in a motorized PC-controlled profiling setup (MM33 and MC-232, Unisense A/ S). Subsequently, vertical $\mathrm{N}_{2} \mathrm{O}$ concentration profiles were recorded at defined time intervals for up to 12 hours with an amperometric $\mathrm{N}_{2} \mathrm{O}$ microsensor [18] $\left(\mathrm{N}_{2} \mathrm{O}-25\right.$, Unisense $\left.\mathrm{A} / \mathrm{S}\right)$ mounted in the micromanipulator.

The microsensors (tip diameter $25 \mu \mathrm{m}$ ) were connected to a picoammeter (PA2000, Unisense A/S) and positioned manually onto the upper surface of the sputum sample. Profile measurements were taken by movement of the sensor in vertical steps of 100 or $200 \mu \mathrm{m}$ through the sputum sample. Positioning and data acquisition were controlled by dedicated software (Sensortrace Pro 2.0, Unisense A/S). The software was set to wait 3 seconds for the $\mathrm{O}_{2}$-microprofile and 5 seconds for the $\mathrm{N}_{2} \mathrm{O}$-microprofile, before actual measurement and subsequent movement of the sensors to the next measuring depth. The interval between each cycle of profile measurements was 10 seconds.

The $\mathrm{O}_{2}$-microsensor was linearly calibrated by measuring the sensor signal in an alkaline sodium ascorbate solution (zero $\mathrm{O}_{2}$ ) and in air saturated free phosphate buffered saline (PBS) at experimental temperature and salinity. The $\mathrm{O}_{2}$ concentration in air saturated water was determined from the known temperature and salinity according to [58]. The $\mathrm{N}_{2} \mathrm{O}$-microsensor was linearly calibrated according to [18] by measuring sensor signals in $\mathrm{N}_{2} \mathrm{O}$ free PBS at experimental temperature and salinity and in PBS with sequential addition of a known volume of $\mathrm{N}_{2} \mathrm{O}$ saturated PBS up

Table 2. Demographic data of the patients.

\begin{tabular}{|c|c|c|c|}
\hline & \multicolumn{2}{|l|}{ CF patients } & \multirow[t]{2}{*}{ PCD patients } \\
\hline & \multicolumn{2}{|c|}{ Infectious status } & \\
\hline & P. aeruginosa & S. aureus & H. influenzae \\
\hline Number (male) & $20(10)$ & $1(1)$ & $2(0)$ \\
\hline Age (years)* & $39(24-50)$ & 17 & $32(27-36)$ \\
\hline $\begin{array}{l}\text { Duration of chronic infection } \\
\text { (years) })^{* * * *}\end{array}$ & $19(4-38)$ & & \\
\hline $\mathrm{FEV}_{1}(\%)^{*}$ & $56(23-96)$ & 75 & 89 (70-109) \\
\hline FVC (\%)* & $88(46-139)$ & 82 & $110(95-125)$ \\
\hline
\end{tabular}

*Values are medians (range).

*Duration of chronic infection is only recorded for $P$. aeruginosa infections.

FEV $_{1}$, forced expiratory volume in $1 \mathrm{~s}$.

FVC, forced vital capacity.

doi:10.1371/journal.pone.0084353.t002 
to a final concentration of $100 \mu \mathrm{M} \mathrm{N} \mathrm{N}_{2} \mathrm{O}$. The $\mathrm{N}_{2} \mathrm{O}$ concentration in saturated PBS was determined according to [59].

$\mathbf{N O}_{3}{ }^{-}$and $\mathbf{N O}_{2}{ }^{-}$quantification. The concentration of $\mathrm{NO}_{3}{ }^{-}$and $\mathrm{NO}_{2}{ }^{-}$in sputum was measured in 20 samples. From each sputum sample, $0.1 \mathrm{ml}$ was aspired with a syringe and was immediately diluted $10 \mathrm{x}$ in $\mathrm{PBS}$ and stored at $-20^{\circ} \mathrm{C}$ for later analysis. The remaining sample was incubated in a glass vial at $37^{\circ} \mathrm{C}$ for $24 \mathrm{~h}$ before dilution $10 \mathrm{x}$ in PBS and storage at $-20^{\circ} \mathrm{C}$. The $\mathrm{NO}_{3}{ }^{-}$and $\mathrm{NO}_{2}{ }^{-}$levels in the sputum were measured using the Griess colorimetric reaction (no. 780001, Cayman Chemicals, USA) according to the manufacturer's recommendations. For this, sputum samples were transferred to a 96 well microtiter plate. $\mathrm{NO}_{2}{ }^{-}$concentration was estimated by addition of the Griess Reagent for 10 minutes, whereby $\mathrm{NO}_{2}{ }^{-}$was converted into a purple azo-compound, which was quantitated by the optical density at $540-550 \mathrm{~nm}$ measured with an ELISA plate reader (Thermo Scientific Multiskan EX, Thermo Fisher Scientific Inc, BioImage, Denmark). Total $\mathrm{NO}_{3}{ }^{-}$and $\mathrm{NO}_{2}{ }^{-}$levels were estimated by a two-step analysis process: The first step converted $\mathrm{NO}_{3}{ }^{-}$to $\mathrm{NO}_{2}{ }^{-}$utilizing $\mathrm{NO}_{3}{ }^{-}$reductase. After incubation for 2 hours, the next step involved the addition of the Griess Reagent, whereby $\mathrm{NO}_{2}{ }^{-}$was converted into a purple azo-compound. After incubation with Griess Reagent for 10 minutes, the optical density at $540-550 \mathrm{~nm}$ was measured with an ELISA plate reader (Thermo Scientific Multiskan EX, Thermo Fisher Scientific Inc, BioImage, Denmark). $\mathrm{A} \mathrm{NO}_{3}{ }^{-}$standard curve was used for determination of total $\mathrm{NO}_{3}{ }^{-}$and $\mathrm{NO}_{2}{ }^{-}$concentration, while a $\mathrm{NO}_{2}{ }^{-}$standard curve was used for determination of $\mathrm{NO}_{2}{ }^{-}$alone. The concentration of $\mathrm{NO}_{3}{ }^{-}$was calculated as the difference between the $\mathrm{NO}_{3}{ }^{-}$concentration and the total $\mathrm{NO}_{3}{ }^{-}$and $\mathrm{NO}_{2}{ }^{-}$ concentration.

Galculations of $\mathbf{N}_{2} \mathbf{O}$ production rates. The local $\mathrm{N}_{2} \mathrm{O}$ fluxes in sputum samples were calculated from the measured $\mathrm{N}_{2} \mathrm{O}$

\section{References}

1. Riordan JR, Rommens JM, Kerem B, Alon N, Rozmahel R, et al. (1989) Identification of the cystic fibrosis gene: cloning and characterization of complementary DNA. Science 245: 1066-1073.

2. Knowles MR, Boucher RC (2002) Mucus clearance as a primary innate defense mechanism for mammalian airways. J Clin Invest 109: 571-577.

3. Boucher RC (2007) Evidence for airway surface dehydration as the initiating event in CF airway disease. J Intern Med 261: 5-16.

4. Koch C, Høiby N (1993) Pathogenesis of cystic fibrosis. Lancet 341: 1065-1069.

5. Koch C, Høiby N (2000) Diagnosis and treatment of cystic fibrosis. Respiration 67: 239-247.

6. Worlitzsch D, Tarran R, Ulrich M, Schwab U, Cekici A, et al. (2002) Effects of reduced mucus oxygen concentration in airway Pseudomonas infections of cystic fibrosis patients. J Clin Invest 109: 317-325.

7. Bjarnsholt T, Jensen PØ, Fiandaca MJ, Pedersen J, Hansen CR, et al. (2009) Pseudomonas aeruginosa biofilms in the respiratory tract of cystic fibrosis patients. Pediatr Pulmonol 44: 547-558.

8. Yang L, Haagensen JA, Jelsbak L, Johansen HK, Sternberg C, et al. (2008) In situ growth rates and biofilm development of Pseudomonas aeruginosa populations in chronic lung infections. J Bacteriol 190: 2767-2776.

9. Pedersen SS, Moller H, Espersen F, Sorensen CH, Jensen T, et al. (1992). Mucosal immunity to Pseudomonas aeruginosa alginate in cystic fibrosis. APMIS 100: $326-334$.

10. Bjarnsholt T, Jensen PØ, Burmolle M, Hentzer M, Haagensen JA, et al. (2005) Pseudomonas aeruginosa tolerance to tobramycin, hydrogen peroxide and polymorphonuclear leukocytes is quorum-sensing dependent. Microbiology 151: 373-383.

11. Jensen PØ, Bjarnsholt T, Phipps R, Rasmussen TB, Calum H, et al. (2007) Rapid necrotic killing of polymorphonuclear leukocytes is caused by quorumsensing-controlled production of rhamnolipid by Pseudomonas aeruginosa. Microbiology 153: 1329-1338.

12. van GM, Christensen LD, Alhede M, Phipps R, Jensen PØ, et al. (2009) Inactivation of the rhlA gene in Pseudomonas aeruginosa prevents rhamnolipid production, disabling the protection against polymorphonuclear leukocytes. APMIS 117: 537-546.

13. Alhede M, Bjarnsholt T, Jensen PØ, Phipps RK, Moser C, et al. (2009) Pseudomonas aeruginosa recognizes and responds aggressively to the presence of polymorphonuclear leukocytes. Microbiology 155: 3500-3508. concentration gradient in the uppermost oxic sputum layer. It was assumed that no production or consumption of $\mathrm{N}_{2} \mathrm{O}$ occurred in the presence of $\mathrm{O}_{2}$. The flux was calculated using a modified version of Fick's $1^{\text {st }}$ law of diffusion [60], where the slope of the profile in the sputum surface layer was calculated from the three uppermost measured concentrations (measurement a, b and c):

$$
J=0.5\left[-D \frac{C_{a}-C_{b}}{x_{a}-x_{b}}\right]+0.5\left[-D \frac{C_{b}-C_{c}}{x_{b}-x_{c}}\right]
$$

where $\mathcal{f}$ is the flux of $\mathrm{N}_{2} \mathrm{O}\left(\mathrm{nmol} \mathrm{N}_{2} \mathrm{O} \mathrm{cm} \mathrm{cm}^{-1}\right.$ ), D is the molecular diffusion coefficient of $\mathrm{N}_{2} \mathrm{O}$ in water at $37^{\circ} \mathrm{C}$ $\left(2.76 \times 10^{-5} \mathrm{~cm}^{2} \mathrm{~s}^{-1}\right)$ [61] and $\mathrm{C}$ is the concentration of $\mathrm{N}_{2} \mathrm{O}$ $\left(\mu\right.$ mol liter $\left.^{-1}\right)$ at depth $\mathrm{x}_{\mathrm{n}}$, where $\mathrm{n}=\mathrm{a}$, b or $\mathrm{c}$ denote 3 subsequent depths of measurement. The cumulated $\mathrm{N}_{2} \mathrm{O}$ emission was calculated by assuming linear changes between subsequent measurements. Net production and net consumption rates of $\mathrm{N}_{2} \mathrm{O}$ in particular sputum layers were calculated from the slopes of linear increase and decrease of $\mathrm{N}_{2} \mathrm{O}$ concentration at particular measuring depths in the sputum samples $[62,63]$.

Statistical Analyses. Statistical significance was evaluated by Wilcoxon Signed Rank Test and by Students T-test. A p value $<0.05$ was considered statistically significant. The tests were performed with Prism 4.0c (GraphPad Software, La Jolla, California, USA).

\section{Author Contributions}

Conceived and designed the experiments: PØJ M. Kolpen M. Kühl. Performed the experiments: PØJ M. Kolpen M. Kühl CRH. Analyzed the data: PØJ M. Kolpen M. Kühl LL. Contributed reagents/materials/ analysis tools: PØJ M. Kolpen M. Kühl CRH TP NH. Wrote the paper: PØJ M. Kolpen M. Kühl TB CM AK NH.
14. Kolpen M, Hansen CR, Bjarnsholt T, Moser C, Christensen LD, et al. (2010) Polymorphonuclear leucocytes consume oxygen in sputum from chronic Pseudomonas aeruginosa pneumonia in cystic fibrosis. Thorax 65: 57-62.

15. Hassett DJ, Cuppoletti J, Trapnell B, Lymar SV, Rowe JJ, et al. (2002) Anaerobic metabolism and quorum sensing by Pseudomonas aeruginosa biofilms in chronically infected cystic fibrosis airways: rethinking antibiotic treatment strategies and drug targets. Adv Drug Deliv Rev 54: 1425-1443.

16. Yoon SS, Hennigan RF, Hilliard GM, Ochsner UA, Parvatiyar K, et al. (2002) Pseudomonas aeruginosa anaerobic respiration in biofilms: relationships to cystic fibrosis pathogenesis. Dev Cell 3: 593-603. S1534580702002952 [pii].

17. Zumft WG (1997) Cell biology and molecular basis of denitrification. Microbiol Mol Biol Rev 61: 533-616.

18. Andersen K, Kjær T, Revsbech NP (2001) An oxygen insentitive microsensor for nitrous oxide. Sensors \& Actuators B: Chemical 81: 42-48.

19. Richardson DJ (2000) Bacterial respiration: a flexible process for a changing environment. Microbiology 146 (Pt 3): 551-571.

20. Philippot L (2002) Denitrifying genes in bacterial and Archaeal genomes. Biochim Biophys Acta 1577: 355-376.

21. Philippot L (2005) Denitrification in pathogenic bacteria: for better or worst? Trends Microbiol 13: 191-192.

22. Zumft WG (2005) Nitric oxide reductases of prokaryotes with emphasis on the respiratory, heme-copper oxidase type. J Inorg Biochem 99: 194-215.

23. Schreiber F, Stief P, Gieseke A, Heisterkamp IM, Verstraete W, et al. (2010) Denitrification in human dental plaque. BMC Biol 8: 24.

24. Mitsui T, Kondo T (2004) Increased breath nitrous oxide after ingesting nitrate in patients with atrophic gastritis and partial gastrectomy. Clin Chim Acta 345: $129-133$.

25. Hino T, Matsumoto Y, Nagano S, Sugimoto H, Fukumori Y, et al. (2010) Structural basis of biological $\mathrm{N}_{2} \mathrm{O}$ generation by bacterial nitric oxide reductase. Science 330: 1666-1670.

26. Arai H, Igarashi Y, Kodama T (1995) The structural genes for nitric oxide reductase from Pseudomonas aeruginosa. Biochim Biophys Acta 1261: 279-284.

27. Gaston B, Ratjen F, Vaughan JW, Malhotra NR, Canady RG, et al. (2002) Nitrogen redox balance in the cystic fibrosis airway: effects of antipseudomonal therapy. Am J Respir Crit Care Med 165: 387-390. 
28. SooHoo CK, Hollocher TC (1991) Purification and characterization of nitrous oxide reductase from Pseudomonas aeruginosa strain P2. J Biol Chem 266: 2203 2209.

29. Son MS, Matthews WJ Jr, Kang Y, Nguyen DT, Hoang TT (2007) In vivo evidence of Pseudomonas aeruginosa nutrient acquisition and pathogenesis in the lungs of cystic fibrosis patients. Infect Immun 75: 5313-5324.

30. Hassett DJ (1996) Anaerobic production of alginate by Pseudomonas aeruginosa: alginate restricts diffusion of oxygen. J Bacteriol 178: 7322-7325.

31. Jones KL, Hegab AH, Hillman BC, Simpson KL, Jinkins PA, et al. (2000) Elevation of nitrotyrosine and nitrate concentrations in cystic fibrosis sputum. Pediatr Pulmonol 30: 79-85.

32. Palmer KL, Brown SA, Whiteley M (2007) Membrane-bound nitrate reductase is required for anaerobic growth in cystic fibrosis sputum. J Bacteriol 189: 4449 4455 .

33. Grasemann H, Michler E, Wallot M, Ratjen F (1997) Decreased concentration of exhaled nitric oxide (NO) in patients with cystic fibrosis. Pediatr Pulmonol 24: 173-177.

34. Linnane SJ, Keatings VM, Costello CM, Moynihan JB, O'Connor CM, et al. (1998) Total sputum nitrate plus nitrite is raised during acute pulmonary infection in cystic fibrosis. Am J Respir Crit Care Med 158: 207-212.

35. Ratjen F, Gartig S, Wiesemann HG, Grasemann H (1999) Effect of inhaled nitric oxide on pulmonary function in cystic fibrosis. Respir Med 93: 579-583.

36. Grasemann H, Grasemann C, Kurtz F, Tietze-Schillings G, Vester U, et al. (2005) Oral L-arginine supplementation in cystic fibrosis patients: a placebocontrolled study. Eur Respir J 25: 62-68.

37. Grasemann H, Tullis E, Ratjen F (2013) A randomized controlled trial of inhaled l-Arginine in patients with cystic fibrosis. J Cyst Fibros. Available: http://dx.doi.org/10.1016/j.jcf.2012.12.008.

38. Einsle O, Messerschmidt A, Stach P, Bourenkov GP, Bartunik HD, et al. (1999) Structure of cytochrome c nitrite reductase. Nature 400: 476-480.

39. Einsle O, Messerschmidt A, Huber R, Kroneck PMH, Neese F (2002) Mechanism of the six-electron reduction of nitrite to ammonia by cytochrome c nitrite reductase. J Am Chem Soc 124; 11737-11745.

40. Planelles G (2007) Ammonium homeostasis and human Rhesus glycoproteins. Nephron Physiol 105; 11-17.

41. Williams DR, Rowe JJ, Romero P, Eagon RG (1978) Denitrifying Pseudomonas aeruginosa: some parameters of growth and active transport. Appl Environ Microbiol 36: 257-263.

42. Hoffman LR, Richardson AR, Houston LS, Kulasekara HD, Martens-Habbena W, et al. (2010) Nutrient availability as a mechanism for selection of antibiotic tolerant Pseudomonas aeruginosa within the CF airway. PLoS Pathog 6: e1000712.

43. Thomas KL, Lloyd D, Boddy L (1994) Effects of oxygen, $\mathrm{pH}$ and nitrate concentration on denitrification by Pseudomonas species. FEMS Microbiol Lett 118: 181-186.

44. Seneterre E, Paganin F, Bruel JM, Michel FB, Bousquet J (1994) Measurement of the internal size of bronchi using high resolution computed tomography (HRCT). Eur Respir J 7: 596-600.

45. Hampton T, Armstrong S, Russell WJ (2000) Estimating the diameter of the left main bronchus. Anaesth Intensive Care 28: 540-542.

46. Arai H (2011) Regulation and Function of Versatile Aerobic and Anaerobic Respiratory Metabolism in Pseudomonas aeruginosa. Front Microbiol 2: 103.
47. Beckmann C, Brittnacher M, Ernst R, Mayer-Hamblett N, Miller SI, et al. (2005) Use of phage display to identify potential Pseudomonas aeruginosa gene products relevant to early cystic fibrosis airway infections. Infect Immun 73: $444-452$.

48. Van Alst NE, Wellington M, Clark VL, Haidaris CG, Iglewski BH (2009) Nitrite reductase $\mathrm{NirS}$ is required for type III secretion system expression and virulence in the human monocyte cell line THP-1 by Pseudomonas aeruginosa. Infect Immun 77: $4446-4454$.

49. Williams DR, Rowe JJ, Romero P, Eagon RG (1978) Denitrifying Pseudomonas aeruginosa: some parameters of growth and active transport. Appl Environ Microbiol 36: 257-263.

50. Borriello G, Werner E, Roe F, Kim AM, Ehrlich GD, et al (2004) Oxygen limitation contributes to antibiotic tolerance of Pseudomonas aeruginosa in biofilms. Antimicrob Agents Chemother 48: 2659-2664.

51. Lee B, Schjerling CK, Kirkby N, Hoffmann N, Borup R, et al (2011) Mucoid Pseudomonas aeruginosa isolates maintain the biofilm formation capacity and the gene expression profiles during the chronic lung infection of CF patients. APMIS 119: $263-274$.

52. Kakishima K, Shiratsuchi A, Taoka A, Nakanishi Y, Fukumori Y (2007) Participation of nitric oxide reductase in survival of Pseudomonas aeruginosa in LPSactivated macrophages. Biochem Biophys Res Commun 355: 587-591.

53. Arai H, Iiyama K (2013) Role of nitric oxide-detoxifying enzymes in the virulence of Pseudomonas aeruginosa against the silkworm, Bombyx mori. Biosci Biotechnol Biochem 77: 198-200. DN/JST.JSTAGE/bbb/120656 [pii].

54. Shimizu T, Tsutsuki H, Matsumoto A, Nakaya H, Noda M (2012) The nitric oxide reductase of enterohaemorrhagic Escherichia coli plays an important role for the survival within macrophages. Mol Microbiol 85: 492-512.

55. Stevanin TM, Moir JW, Read RC (2005) Nitric oxide detoxification systems enhance survival of Neisseria meningitidis in human macrophages and in nasopharyngeal mucosa. Infect Immun 73: 3322-3329.

56. Loisel-Meyer S, Jimenez de Bagues MP, Basseres E, Dornand J, Kohler S, et al. (2006) Requirement of norD for Brucella suis virulence in a murine model of in vitro and in vivo infection. Infect Immun 74: 1973-1976.

57. Høiby N (2000) Microbiology of cystic fibrosis. In: Hodson ME GD, editors. Cystic fibrosis. London, UK: Arnold. pp. 83-107.

58. Gundersen JK, Glud RN, Ramsing NB (1998) Predicting the signal of O microsensors from physical dimensions, temperature, salinity, and $\mathrm{O}_{2}$ concentration. Limnol Oceanogr 43: 1932-1937.

59. Weiss RF, Price BA (1980) Nitrous oxide solubility in water and seawater. Marine Chemistry 8: 347-359.

60. de Beer D, Stoodley P (2006) Microbial biofilms. In: Dworkin M, Falkow S, Rosenberg E, Schleifer KH, Stackebrandt E, editors. The Prokaryotes. New York: Springer Science. pp. 904-937.

61. Broecker WS, Peng TH (1974) Gas-exchange rates between air and sea. Tellus 26: $21-35$.

62. Markfoged R, Nielsen LP, Nyord T, Ottosen LDM, Revsbech NP (2013 Transient $\mathrm{N}_{2} \mathrm{O}$ accumulation and emission caused by $\mathrm{O}_{2}$ depletion in soil after liquid manure injection. European journal of soil science 62: 541-550.

63. Liengaard L, Nielsen LP, Revsbech NP, Priemé A, Elberling B, et al. (2013) Extreme emission of $\mathrm{N}_{2} \mathrm{O}$ from tropical wetland soil (Pantanal, South America). Frontiers in Microbiology 3: 433. doi: 10.3389/fmicb.2012.00433. 